\title{
Concomitant systemic lupus erythematosus and ankylosing spondylitis
}

Ignazio Olivieri, Gabriele Gemignani, Michela Balagi, Antonio Pasquariello, Giuseppe Gremignai, Giampiero Pasero

\begin{abstract}
The case is reported of a 42 year old white woman meeting currently used diagnostic criteria for both ankylosing spondylitis and systemic lupus erythematosus (SLE). As found in a previously described similar case of a black man, HLA typing showed antigens associated with both SLE and seronegative spondyloarthropathy. This case thus supports the hypothesis that the two diseases occur together only when this rare combination of HLA antigens is present.
\end{abstract}

The coexistence of systemic lupus erythematosus (SLE) and seronegative spondyloarthropathy is very rare. Only a few cases have been reported. ${ }^{1-5}$

We describe here another case of this coexistence. As in the case reported by Nashel $e t$ $a l,{ }^{1}$ our patient showed an unusual combination of HLA antigens associated with both seronegative spondyloarthropathy and SLE.

\section{Case report}

A 42 year old white woman was admitted to our hospital in January 1986. About one year before, SLE had been diagnosed and treatment started with corticosteroids and chloroquine.

Her medical history showed episodes of sciatic pain during the postpartum period in 1979 , episodes of inflammatory low back pain and stiffness in the past five years, recurrent episodes of arthritis of the knees, ankles, and wrists and of Achilles tendinitis between 1980 and 1983, malar rash, oral ulcers, alopecia, and Raynaud's phenomenon since 1983.

Her family history was negative for both SLE

Rheumatic Disease Unit of the Institute of Medical Pathology 1, University of Pisa, Italy

I Olivieri

G Gemignani

M Balagi

G Pasero

Division of Nephrology, 'Santa Chiara' Hospital, Pisa, Italy

A Pasquariello

Blood Transfusion

Service, 'Santa Chiara'

Hospital, Pisa, Italy

G Gremignai

Correspondence to:

Dr Ignazio Olivieri

Istituto di Patologia Medica 1

Servizio di Reumatologia,

via Roma 2, 56100 Pisa, Italy.

Accepted for publication

10 July 1989 and seronegative spondyloarthropathy.

Physical examination showed the classic butterfly rash over the cheeks and the bridge of the nose, asymptomatic mouth ulcers on the hard and soft palate, alopecia, digital vasculitis and tenderness on both sacroiliac joints and both Achilles tendons. Lumbar and cervical spine movement was normal. Chest expansion was $2 \cdot 5 \mathrm{~cm}$.

Investigations showed erythrocyte sedimentation rate (Westergren) $25 \mathrm{~mm} / \mathrm{lst} \mathrm{h}, \mathrm{C}$ reactive protein $36 \mathrm{mg} / \mathrm{l}$ (normal $<5 \mathrm{mg} / \mathrm{l}$ ), positive antinuclear antibody test $(1 / 640$, diffuse pattern), positive anti-double-stranded DNA antibody, reduced serum complement concentrations with a total haemolytic complement $\left(\mathrm{CH}_{50}\right) 122 \mathrm{U} / \mathrm{ml}$ (normal 150-210 U/ml), C4 10 $\mathrm{mg} / \mathrm{l}$ (normal $200-400 \mathrm{mg} / \mathrm{l}$ ), and C3 $430 \mathrm{mg} / \mathrm{l}$ (normal 550-1200 mg/l). Tests for the rheuma- toid factor, the anti-extractable nuclear antigen antibody, and the Venereal Disease Research Laboratory test were negative. HLA typing showed A2, A24, B18, B27, Cw2, DR3, DR7, $\mathrm{DQw2}$, and $\mathrm{DQw} 3$ antigens.

Immunofluorescent studies (lupus band test) disclosed deposits of gammaglobulin and complement components at the dermal-epidermal junction.

An anteroposterior view (fig 1) of the pelvis showed grade 3 bilateral sacroiliitis. Lumbar and dorsal spine radiographs showed subchondral osteitis of the upper corner of the last dorsal vertebrae and of the first lumbar ones. Radiographs of the cervical spine were normal. The lateral view of the calcaneus showed spurs at the insertion of both Achilles tendons.

Prednisone was increased from 6 to 12 $\mathrm{mg} /$ day. Subsequently this dose was tapered to $5 \mathrm{mg} /$ day.

In July 1987 the patient had proteinuria and was admitted to our institute again for a renal biopsy.

Laboratory evaluation showed erythrocyte sedimentation rate $36 \mathrm{~mm} / \mathrm{lst} \mathrm{h}$, antinuclear antibody strongly positive with a diffuse pattern, anti-dsDNA antibody positive, $\mathrm{CH}_{50} 98 \mathrm{U} / \mathrm{ml}$, C4 $60 \mathrm{mg} / \mathrm{l}$, C3 $380 \mathrm{mg} / 1,24$ hour urine protein concentration $4.5 \mathrm{~g}$, and normal serum creatinine concentrations.

A light microscopy study of the renal biopsy specimen (fig 2) disclosed findings of diffuse proliferative lupus nephritis, including mesangial and endothelial cell proliferation, 'wire loops', epithelial crescents, nuclear pyknosis and karyorrhexis, and infiltration by polymorphonuclear leucocytes.

Under immunofluorescence diffuse granular deposits of IgG, IgM, C3, and Clq were seen along the basement membrane and the capillary wall.

The patient was given $40 \mathrm{mg} /$ day prednisone. This dose was gradually reduced to the current dose of $5 \mathrm{mg} /$ day.

\section{Discussion}

Our patient meets both the New York criteria for ankylosing spondylitis ${ }^{6}$ and the American Rheumatism Association criteria for SLE. ${ }^{7}$

The coexistence in the same patient of SLE and seronegative spondyloarthropathy is much less than the expected concurrence calculated on the basis of the prevalence of each of them in the general population. ${ }^{1}$ Only a few cases, to our knowledge, have been reported. ${ }^{1-5}$ Some authors have reported a high prevalence of sacroiliitis in male patients with SLE, ${ }^{89}$ but none of these 


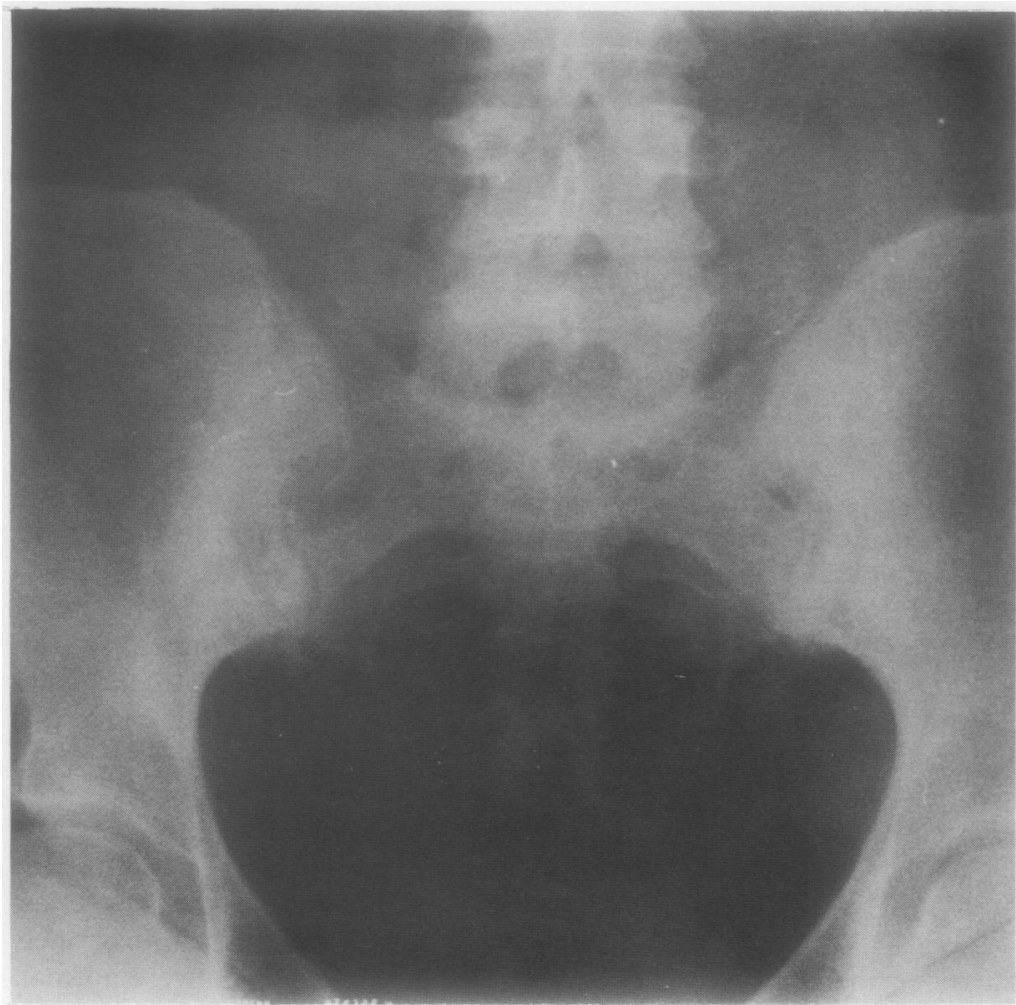

Figure 1: Anteroposterior view of the pelvis showing sclerosis, narrowing, and erosions of both sacroiliac joints.

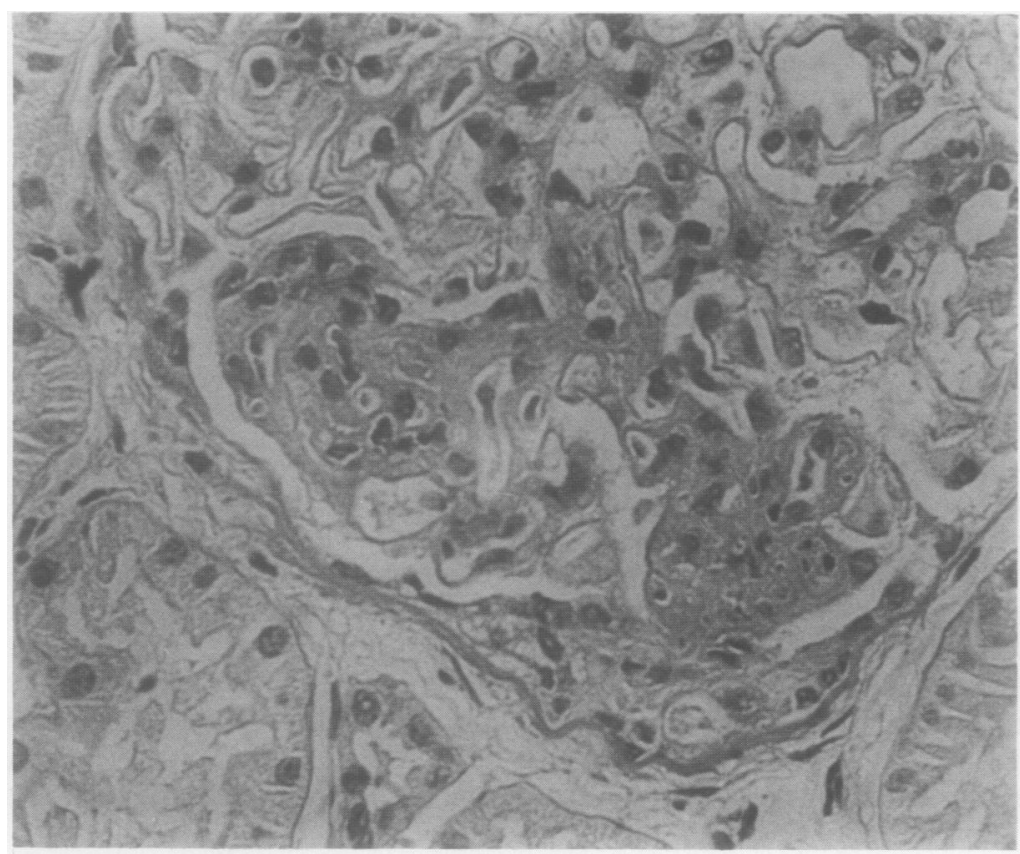

Figure 2: Light microscopy showing diffuse proliferative nephritis.

studies used controls. As a high observer variation exists in the grading of sacroiliac joint plain films, ${ }^{10}$ control groups would have been advisable. In other studies a high prevalence of scintigraphic sacroiliitis in patients with active SLE was reported by De Smet $e t a l^{11}$ and Gosset et al. ${ }^{12}$ The value of quantitative scintigraphy of the sacroiliac joints in detecting early sacroiliitis before the appearance of radiological changes is controversial, however. ${ }^{1314}$
In 1982 Nashel et al reported the case of a 43 year old black man affected by both ankylosing spondylitis and SLE. ${ }^{1}$ HLA typing showed Al, A2, B8, B27, C3, DR2, and DR3 antigens. The authors suggested that the rarity of the coexistence of SLE and ankylosing spondylitis in the same patient might depend on the fact that the B27 antigen rarely exists in combination with the DR2 or DR3 antigens, which are associated with SLE, as confirmed by studies of haplotype frequencies in American black subjects.

Our patient, like that of Nashel et al, showed both the B27 antigen, which is associated with ankylosing spondylitis and the other seronegative spondarthritides, ${ }^{15}$ and the DR3 antigen, which is associated with SLE. ${ }^{16}$ Studies of haplotype frequencies have shown that in white subjects also the B27 antigen exists only exceptionally with DR3. ${ }^{17}$

Our report confirms the hypothesis of Nashel et al that SLE and seronegative spondyloarthropathy coexist only when a rare combination of genetically determined markers occurs. ${ }^{1}$

1 Nashel D J, Leonard A, Mann D L, Guccion J G, Katz A L, Sliwinski A J. Ankylosing spondylitis and systemic lupus erythematosus: a rare HLA combination. Arch Intern Med 1982; 142: 1227-8.

2 Webb S, Segura F, Cervantes F, et al. Systemic lupus erythematosus and amyloidosis. Arthritis Rheum 1979; 22: $554-6$.

3 Kappes J, Schoepflin G, Bardana E, Bennet R. Lupoid sacroarthropathy: a previously undescribed association sacroarthropathy: a previously undescribed
[Abstract]. Arthritis Rheum 1980; 23: 699-700.

4 Aisen P S, Cronstein B N, Kramer S B. Systemic lupus erythematosus in a patient with Reiter's syndrome. Arthritis Rheum 1983; 26: 1405-8

5 Bruhl W, Chrzczonowski Z. Coexistence of ankylosing arthritis of the spine and systemic lupus erythematosus. Reumatologia 1978; 16: 547-9.

6 Bennet P H, Wood P H N. Population studies of the rheumatic diseases. Proceedings of the Third International Symposium, New York 1966. Amsterdam: Excerpta Medica, 1968: 456-7.

7 Tan E M, Cohen A S, Fries J F, et al. The 1982 revised criteria for the classification of systemic lupus erythematosus. Arthritis Rheum 1982; 25: 1271-7.

8 Nassonova V A, Alekberova Z S, Folomeyev M Yu, Mylov

N M. Sacroiliitis in male systemic lupus erythematosus. Scand f Rhermatol [Suppl] 1984; 52: 23-9.

9 Vivas J, Tiliakos N A. Sacroiliitis in male systemic lupu erythematosus. Scand $\mathcal{I}$ Rheumatol 1985; 14: 441

10 Yazici H, Turunç M, Ozdogăn H, Yurdakul S, Akinci A Barnes C G. Observer variation in grading sacroiliac radiographs might be a cause of 'sacroiliitis' reported in certain disease states. Ann Rheum Dis 1987; 46: 139-45.

11 De Smet A A, Mahmood T, Robinson R G, Lindsley H B. Elevated sacroiliac joint uptake ratios in systemic lupus erythematosus. $A \mathcal{F} R$ 1984; 143: $351-4$.

12 Gosset D, Foucher C, Lecouffe P, Savinel P. Asymptomatic sacroiliitis in systemic lupus erythematosus. $\mathcal{f}$ Rheumato 1988; 15: 152-3.

13 Kjällman $M$, Nylèn $O$, Hansés $M$. Evaluation of quantitative sacroiliac scintigraphy in the early diagnosis of ankylosing spondylitis. Scand 7 Rheumatol 1986; 15: 265-71.

14 Namey T C. Nuclear medicine, and special radiologic imaging and technique in the diagnosis of rheumatic diseases. In: Kelley W N, Harris E D Jr, Ruddy S, Sledge C B, eds. Textbook of reumatology. 2nd ed. Philadelphia Saunders, 1985: 608-40.

15 Moll J M H, Haslock I, Wright V. Seronegative spondarthritides. In: Scott J T, ed. Copeman's textbook of the rheumatic diseases. 6th ed. Edinburgh: Churchill Livingstone, 1986: $723-44$.

16 Reinertsen J L, Klippel J H, Johnson A H, Steinberg A D, Decker J L, Mann D L. B-lymphocyte alloantigens associated with systemic lupus erythematosus. $N$ Engl $\mathcal{f}$ Med 1978; 299: 515-8.

17 Bauer M P, Danilovs J A. Reference tables of two and threelocus haplotype frequencies of $\mathrm{HLA}-\mathrm{A}, \mathrm{B}, \mathrm{C}, \mathrm{DR}, \mathrm{BF}$, and GLO. In: Terasaki P I, ed. Histocompatibility testing 1980. Los Angeles: UCLA Tissue Typing Laboratory, 1980
994-1210. 